\begin{tabular}{|c|c|}
\hline $\begin{array}{r}\text { ARTICLES } \\
\text { ARTICULOS }\end{array}$ & $\begin{array}{l}\text { PROTECTING SOURC } \\
\text { from shield laws to Wikileaks }\end{array}$ \\
\hline $\begin{array}{r}\text { Copyright @ } 2015 \\
\text { SBPjor / Associação } \\
\text { Brasileira de Pesquisa- } \\
\text { dores em Jornalismo }\end{array}$ & $\begin{array}{l}\text { MÉLANIE DUPÉRÉ } \\
\text { Universite Sorbonne Nouvelle - Paris III, France }\end{array}$ \\
\hline
\end{tabular}

\begin{abstract}
This paper focuses on recent developments in the right and ability of journalists to protect their sources' anonymity in the United Kingdom, particularly in light of the Snowden revelations of June 2013, and the significance of collaboration between the global online media organization Wikileaks and mainstream news organisations. It explores two key difficulties faced by journalists: the notion of a qualified professional privilege and the unknown extent of covert requests by public authorities for disclosure involving communications data and metadata. In doing so, it comments upon the opening filled by Wikileaks, which protects its sources' anonymity through high data security and encryption. This paper's findings tend to show that the covert practice of blanket mass digital surveillance of individual communications including journalists' is undermining source protection and the rise of Wikileaks as an alternative model is challenging the traditional role of journalists as mediators and gatekeepers in the digital era.
\end{abstract}

Keywords: Journalism. Mass digital surveillance. Qualified professional privilege. Regulation. Source protection.

\title{
PROTEGENDO FONTES: De Leis de Proteção a Wikileaks
}

RESUMO - Este trabalho se concentra sobre a evolução recente o direito e a capacidade dos jornalistas de proteger o anonimato de suas fontes no Reino Unido, particularmente à luz das revelações de Snowden em junho de 2013, bem como a importância da cooperação entre a organização de mídia online WikiLeaks e as organizações noticiosas. O artigo explora duas dificuldades principais enfrentadas por jornalistas: a noção de um privilégio profissional qualificado e a extensão desconhecida de solicitações de acobertamento de divulgação por autoridades públicas envolvendo comunicações dados e metadados. Ao fazê-lo, o estudo comenta o caso Wikileaks, que protege suas fontes anônimas por meio da alta segurança de dados e criptografia. Os resultados tendem a mostrar que a prática de cobertura de vigilância digital de massa de comunicações individuais, incluindo jornalistas, está a minar a proteção da fonte e a ascensão do Wikileaks como um modelo alternativo está desafiando o papel tradicional de jornalistas como mediadores e gatekeepers na era digital.

Palavras-chave: Jornalismo. Vigilância digital em massa. Privilégio profissional. Regulação. Proteção da fonte.

\section{PROTEGENDO FUENTES: desde las leyes de protección hasta Wikileaks}

RESUMEN - Este trabajo se centra en la evolución reciente de la ley y la capacidad de los periodistas a proteger el anonimato de sus fuentes en el Reino Unido, especialmente a la luz de las revelaciones del Snowden en junio de 2013, así como en la importancia de la cooperación entre la organizacion WikiLeaks e las organizaciones de noticias. El artículo explora dos dificultades principales que enfrentan los periodistas: la noción de un privilegio cualificado y el grado desconocido de solicitudes de encubrimiento para 
la divulgación, de las autoridades públicas que involucran comunicaciones de datos y metadatos. Para esto el estudio enfoca el caso Wikileaks que protege sus fuentes anónimas a través de alta seguridad de datos y encriptación. Los resultados tienden a mostrar que la práctica de la cobertura de vigilancia digital en masa de las comunicaciones individuales, incluidos los periodistas, está socavando la protección de la fuente y el surgimiento de Wikileaks, como un modelo alternativo, desafía el papel tradicional de los periodistas como mediadores y porteros en la era digital.

Palabras clave: Periodismo. Vigilancia digital en masa. Privilegie profesional. Reglamento. Protection de la fuente.

\section{INTRODUCTION}

The concept of press freedom is multi-faceted and complex in its continual search for a balance between the freedom of expression and the right to privacy. There has been much criticism of unethical behaviour within the UK press and questions raised with respect to a general culture of malpractice, as revealed by the News International phone-hacking scandal, first reported by The Guardian in 2009. In particular, calls for greater regulation led to a highly publicized public inquiry chaired by Sir Brian Leveson into British press culture, practices and ethics as well as that of broadcasters and social media. This process culminated in reform of press regulation as enshrined by a royal charter sealed by the Privy Council in 2013 creating oversight for a new press regulator (DCMS and JAVID, 2013). In this context of unethical behaviour by an self-regulated press, it may be all too easy to forget the necessity of certain principles behind a free press, such as journalists being able to protect their sources in the public interest - ensuring the public's right to know about malpractice and illegal activities at all levels in order to hold wrong-doers to account. This paper therefore seeks to explore recent developments in the right and ability of British journalists to protect their sources, particularly in light of the Snowden revelations of June 2013 and the significance of collaboration between the global online not-for-profit media organization Wikileaks and mainstream news organisations.

Firstly, this paper considers the regulatory context of journalistic source protection in the UK. Secondly, it focuses on the 
undermining of source protection through the use of communications surveillance technology, particularly in the aftermath of the Edward Snowden revelations of June 2013. Finally, it explores the rise of Wikileaks as an alternative model for source anonymity and the significance of its cooperation with mainstream media for professional journalism and source protection in the digital era.

\section{THE REGULATORY CONTEXT OF SOURCE PROTECTION}

The ethical imperative of journalists to protect their sources is a widely-held professional principle (DODD; HANNA, 2014, p. 401-402). There is an understanding that reporters need to build a relationship of trust in order to maintain access to sensitive information and thereby play their watchdog role. Indeed, when confidentiality is uncertain, there is an obvious risk of a chillingeffect as potential sources may be dissuaded by the risk of reprisals and/or legal repercussions (DODD; HANNA, 2014, p. 401). It is therefore unsurprising that this ethical imperative is encapsulated in many journalistic codes of conduct in the UK and abroad. Some notable instances include The UK Editors' Code of the newly founded Independent Press Standards Organisation (2014)' , the UK Chartered Institute of Journalists' Code $(2014)^{2}$, the UK National Union of Journalists' Code of Conduct $(2011)^{3}$, the International Federation of Journalists Code of Principles (1954) ${ }^{4}$.

From a legal standpoint, the right of journalists to protect their sources is recognized in the laws or constitutions of around a hundred countries across the world. According to a report from 2007, 'In at least 20 countries, those protections are absolute. Many countries also recognize protection of sources in case law as common law or as part of the constitutional right of free speech' (BANISAR, 2007, p. 4). In 2011, the Parliamentary Assembly of the Council of Europe reaffirmed the right of journalists to protect their sources as a basic condition in order to carry out their work and thus defend the public's right to be informed about issues of public concern (PACE, $2011, \S 2$ ). The Assembly clearly described this right as a necessary professional privilege in order to encourage confidential sources to come forward (PACE, 2011, § 15).

Yet, in domestic UK law, there was little recognition of confidential source protection prior to 1981. Nathan (1984, 
p. 518-22) explains the legal background to the question of journalists' privilege to protect their sources, particularly the English 'Newspaper Rule' dating back as far as 1888, and how this principle developed over time. Applicable only in defamation cases and 'only at the interrogatory stage of litigation' (NATHAN, 1984, p. 521 ), this 'Rule' was established on the basis of the irrelevance of disclosure with regard to the libel charge, rather than any kind of journalistic privilege before the law (NATHAN, 1984, p. 519). Although there was a gradual shift from relevance to privilege in the early twentieth century, by 1937, newspaper immunity was not considered to be based on any principle of law, but rather to constitute an exception to the law (NATHAN, 1984, p. 521). In the early 1960s, the limits of the 'Newspaper Rule' were further defined in the Vassall Inquiry Cases. In particular, journalists Brendan Mulholland and Reg Foster alleged that the British government had failed in its duty to recognise that British admiralty clerk Williams Vassall had been spying for foreign governments.Both journalists were jailed for withholding the identity of their sources and, despite parliamentary debate in the aftermath, no changes to the law were made with respect to court-ordered disclosure of journalists' sources (NATHAN, 1984, p. 522-525).

However, the case of British Steel Corporation Respondents $v$ Granada Television Ltd. Appellants[1980] 3 WLR 774, [1981] AC 1096 marked a turning point and was highly criticized by the press (NATHAN, 1984, p. 536) as the House of Lords judgment found Granada Television Ltd did not have a public interest right to keep its sources of information secret. Following this, Parliament passed an amendment, section 10 of the Contempt of Court Act 1981, which recognized to some extent a watchdog role for the media (FENWICK; PHILLIPSON, 2006, p. 323-324). Although this provision constituted a major step forward for journalists, it stipulated that disclosure may be deemed necessary in the interests of justice or national security or for the prevention of disorder or crime' (Contempt of Court Act 1981) and together these four exceptions are in fact overlapping and potentially very broad' (FENWICK; PHILLIPSON, 2006, p. 323-324). As a result, UK judges tended to give little weight to the general public interest argument in journalists wishing to protect the anonymity of their sources (DODD; HANNA, 2014, p. 403-405). 
However, since the Human Rights Act 1998 came into effect in 2000, the European Convention on Human Rights has been given further effect in UK domestic law, providing journalists with greater protection (DODD; HANNA, 2014, p. 403-405). Indeed, the right to the protection of sources was fully recognised by the Court of Appeal in 2007 as it was deemed 'the approach of the English courts to both section 10 of the 1981 Act and Article 10 of the [European] Convention should be the same' (Mersey Care NHS Trust $v$ Ackroyd[2007] EWCA Civ 101).Yet, as the second part of this paper seeks to demonstrate, the ability of journalists to protect their sources is being undermined through the use of communications surveillance technology.

\section{THE UNDERMINING OF SOURCE PROTECTION USING COMMUNICATIONS SURVEILLANCE TECHNOLOGY}

The Edward Snowden revelations of June 2013 have seriously questioned individual privacy rights and the ability of journalists in particular to protect their sources as well as the extent, morality and legality of the covert mass surveillance programmes operated by the US National Security Agency and the UK Government Communications Headquarters with or without the cooperation of the technology sector. In UK domestic law, the authorisation for these covert actions was given by certificates issued under section 8(4) of the Regulation of Investigatory Powers Act 2000. This poses the problem of compatibility with provisions in the European Convention of Human Rights in favour of respect for private and family life and the protection of sources, as argued in ongoing challenges before the European Court of Human Rights in Big Brother Watch and Others v. the United Kingdom App. $N^{\circ}$ $58170 / 13 E C H R$, filed $4^{\text {th }}$ September 2013 , as well as by the Bureau of Investigative Journalism, lodged $12^{\text {th }}$ September 2014 (Bureau of Investigative Journalism, 2014).

In the past, disclosure of journalists' confidential sources may have been requested by court orders and search warrants on media outlets and journalists' homes. However, the usual safeguards against unwarranted searches and seizures found for instance in the Police and Criminal Evidence Act 1984arein fact regularly circumvented by security services, law enforcement and 
other public authorities through abroad range of RIPA 2000 requests to seize personal communication data and metadata. Instances include police forces, National Crime Agency, Her Majesty's Revenue and Customs, Security Service (Mi5), Secret Intelligence Service (Mi6), Government Communications Headquarters (MAY, 2013: 19). Such requests may be made in the interests of national security, prevention or detection of serious crime, safeguarding of economic well-being of the UK, any international mutual legal assistance agreement (Regulation of Investigatory Powers Act 2000 s. 5(3)). According to the Interception of Communications Commissioner's Office's own figures, there were 514,608 notices and authorisations for obtaining communications data under RIPA 2000in 2013 alone and this figure does not include urgent oral applications (MAY, 2013, p. 22).

The extent of the practice of covertly identifying journalists' sources with RIPA 2000requestsremains unknown (WINTOUR, 2014) and has only very recently been brought into the spotlight by two cases:

(1) During investigation Operation Alice, the Metropolitan police used RIPA 2000 in order to obtain the The Sun's political editor Tom Dunn's telephone records enabling them to identify a source from within the police force, following an altercation at the gates of Downing Street in 2012 between then Government Whip Andrew Mitchell and Officers from the Diplomatic Protection Group (METROPOLITAN POLICE, 2014);

(2) Police gained access to billing and call data of the The Mail on Sunday's News Editor David Dillon and his source, a freelance reporter, helping in the conviction of then Energy Secretary Christopher Huhne in 2013 for perverting the course of justice in the case of a speeding fine dating back to 2003 (CRAVEN, 2014).

Despite a European Court of Justice judgment from April 2014 declaringdirective $2006 / 24$ /EC on data retention and its use by public authorities to be invalid (Digital Rights Ireland Ltd (C-293/12) v Minister for Communications Marine and Natural Resources and Othersand Kärntner Landesregierung (C-594/12) and others),blanket collection of personal communication content and metadata including that of journalists continues in the UK and emergency domestic legislation (Data Retention and Investigatory Powers Act 2014)has done little to abate criticism in the debate over privacy rights, particularly due to an unexplained three-month delay in parliamentary debate. However, following 
mounting pressure, Interception of Communications Officer Sir Paul Kennedy has since stated he has launched an inquiry, requesting 'full details of all investigations that have used RIPA powers to acquire communications data to identify journalistic sources'(TRAVIS, 2014). The Minister of State for Justice and Civil Liberties Simon Hughes has also promised legislative reform (WINTOUR, 2014).

The reality is journalists and news organisations are having to improve their computer and communications security in order to better protect their sources. This leads us to the third and final part of this paper concerned with the rise of Wikileaks as an alternative model of source anonymity and the debate surrounding its significance for professional journalism and source protection in light of its collaboration with mainstream news organizations.

\section{THE RISE OF WIKILEAKS AS AN ALTERNATIVE MODEL OF SOURCE ANONYMITY IN THE DIGITAL ERA}

Originating in the 1990s international Cypherpunks movement, which advocated making cryptographic software free and widely available to guarantee individual privacy and freedom of expression (ASSANGE et al, 2012, p. 88), the online not-for-profit platform Wikileaks was officially launched in 2007. It was based on the concept of wiki or collaborative knowledge, receiving and sharing non-moderated material from anonymous sources, using encryption. It claimed to have received 1.2 million documents within its first year alone (WIKILEAKS, 2008). However, this model was replaced in May 2010 with a more traditional publishing format involving moderating. Wikileaks has also developed its arguments with respect to journalism and source anonymity over time. Indeed, Assangehas been quoted as describing the online platform as 'a source-protection organization and a publishing-protection organization'(BECKETT; BALL, 2012, p. 16), creating a new standard of 'scientific journalism' by making all research data available for the purposes of checking and copying (KHATCHADOURIAN, 2010). The website also states it has 'provided a new model of journalism' (WIKILEAKS, 2011 , seção 1.3).

Of particular interest here is Wikileaks' tentative partnership with major newspapers and television in the 
disclosures of the Afghan and Iraq War Logs, as well as the Diplomatic Cables in 2010 , beginning 25 July, 22 October and 28 November 2010 respectively. The Guardian, The New York Times, Der Spiegel and Channel 4 all collaborated with Wikileaks in the publication of the Afghan War Logs; Julian Assange later brought in Le Monde and EI Pais for the Iraq War Logs (ELLISON, 2011). For Wikileaks this was a 'tactical' alliance (BECKETT, 2012), an opportunity to extend its network of journalists to check and sort through the vast amounts of data and to reach a much wider audience. For these major media outlets this was a chance to gain unprecedented access to and publish material about the reality of war and diplomatic relations.

The process of involving several competing news organisations in an experimental collaborative project with Wikileaks was not without difficulties. Both The Guardian and The New York Times referred to the tense nature of the negotiations:

(1) Vanity Fair contributing editor Ellison (2011) quoted The Guardian's Editor Alan Rusbridger as writing: 'Managing a relationship between a French afternoon paper, a Spanish daily, a German weekly, a paper on NY time, and a bunch of anarchists in hiding is trying!'Not without humour, this statement points to some of theinherent complications of an internationalmulticultural cross-legal boundary project.

(2) New York Times reporter Keller (2011) stated '[...] how journalists from three very different publications would work together without compromising their independence; and how we would all assure an appropriate distance from Julian Assange. We regarded Assange throughout as a source, not as a partner or collaborator'. Indeed, The New York Times did not hesitate to simultaneously publish a highly critical portrayal of Julian Assange (BURNS; SOMAIYA, 2010).

Keller may have been hesitant to describe Wikileaks' work as journalism but he did evoke the risk of a chilling effect on journalism if the US government were to prosecute Wikileaks for its disclosures of sensitive material. He also raised the question as to whether the online organisation had fundamentally changed the way in which journalism is made (KELLER, 2011).Indeed, his concern with distancing himself from Julian Assange's online platform and what it represents reflects the challenge to the traditional role of journalists as gate-keepers and mediators. This unease may be explained in the context of professional journalism ideology. As reporter and academic Canter (2014, p. 149-150) explains: 
Professional [journalism] ideology implies that journalists are distinct from the public due to their exclusive role and status, which is played out via a particular set of conventions and standards [...]made up of the five ideal traits of public service, objectivity, autonomy, immediacy, and ethics.

In contrast to the inherent difficulties of financing and publishing high-quality investigative journalism whilst respecting such a set of standards, particularly for a newspaper industry struggling as a whole with falling sales and losses in advertising (see for instance DAVIES, 2009), Wikileaks does not need to heed such pressures and constraints in order to gather and publish information. For Beckett and Ball (2012, p. 150-151), this online platform constitutes a network exploit in that it takes advantage of the possibilities of connectedness with mainstream media whilst maintaining its own identity. This is explained against a background of 'networks in which citizens and journalists act as curators, connectors and facilitators, as well as in the traditional roles of reporters, analysts and investigators' (BECKETT; BALL, 2012, p. 151). In this context, sources are no longer as dependent on journalists and traditional news organisations.

Four years on from the Afghan, Iraq and Diplomatic Cable disclosures, studies in approaches to ethical journalism online including source-related aspects and their contribution to democracy continue, such as ethical aggregating and crowd sourcing, as journalists are faced with an exponential amount of information access and related quality issues online.(See for instance FRANKLIN; CARLSON, 2013; ZION; CRAIG, 2014).For some Information Society theorists, the expansion of interactive and networked technologies improves democracy as citizens become better informed and are able to hold their representatives to account. For others however, such forms of media may be partially responsible for a decline in democratic participation as citizens become more withdrawn in private spaces consumed with infotainment (WEBSTER, 2014, p. 196-197).In this digital landscape, it is clear in any case that the question of source protection in the United Kingdommust be considered beyond national borders. 


\section{CONCLUSION}

This paper began by considering developments in the notion of a qualified professional privilege with respect to the protection of journalistic sources in its regulatory context. It went on to show how a greater awareness of the covert practice of mass digital surveillance is questioning the possibility of a free press and journalists' ability to protect their sources. It commented in particular on the significance of Wikileaks' collaboration with mainstream news organizations in the Afghan, Iraq and Diplomatic Cable disclosures. This led to questions about the relationship between professional journalism and sources in a digital era. In the future, the ability of journalists to protect their sources will no doubt be increasingly dependent on their computer and communications security measures. The current questioning of UK domestic laws which may breach individual rights to privacy and particularly that of journalists will also need to be resolved, if journalists are to be allowed to play their vital public interest watchdog role in a democratic society.

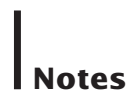

1 According to clause 14, 'Journalists have a moral obligation to protect confidential sources of information.'

2 Principle 2 refers back to the Editors' Code. Principle 7 also states, 'You will maintain the confidences you agreed with any contributors.'

3 According to principle 7, a journalist 'Protects the identity of sources who supply information in confidence and material gathered in the course of her/his work.'

4 According to principle 6, 'The journalist shall observe professional secrecy regarding the source of information obtained in confidence.' 


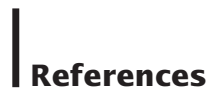

ASSANGE, J. et al. Cypherpunks: Freedom and the Future of the Internet. New York, London: ORBooks, 2012.

BANISAR, D. Silencing Sources: An International Survey of Protections and Threats to Journalists'Sources. London: Privacy International, 2007. Available at: https://wikileaks.org/w/images/c/c0/ Silencingsources.pdf Accessed: 01 Aug. 2014.

BECKETT,C. Wikileaks: Lessons for Media Policy and Regulation. In: LSE Polis, 5 Mar. 2012. Available at: http://blogs.Ise.ac.uk/polis/2012/03/05/ wikileaks-lessons-for-press-policy-regulation/ Accessed: 01 Oct. 2014).

BECKETT, C; BALL, J. Wikileaks. News in the Networked Era. Cambridge: Polity Press, 2012.

Big Brother Watch and Others $v$ the United KingdomApp. $\mathbf{N}^{\circ}$ 58170/13ECHR. Available at: http://hudoc.echr.coe.int/sites/eng/ pages/search.aspx?i=001 140713\#\{\%22itemid\%22:[\%22001-140713\%22]\} Accessed: 01 Aug. 2014.

\section{British Steel Corporation Respondents v Granada Television Ltd. Appellants [1980] 3 WLR 774,[1981] AC 1096.}

Bureau of Investigative Journalism. A Summary of the Bureau's Application to the European Court of Human Rights. London: Bureau of Investigative Journalism, 2014. Available at: http://www. thebureauinvestigates.com/2014/09/14/a-summary-of-the-bureausapplication-to-the-european-court-of-human-rights/ Accessed: 01 Sep. 2014).

BURNS, J; SOMAIYA, R. Wikileaks Founder on the Run, Trailed by Notoriety. The New York Times, 23 Oct. 2010. Available at: http://www. nytimes.com/2010/10/24/world/24assange.html?pagewanted=all\&_r=0 Accessed: 01 Oct. 2014.

CANTER, L. Collaboration. In: ZION, L. (ed.); CRAIG, D. (ed.). Ethics for Digital Journalists. New York and London: Routledge, 2014, p. 145158.

Chartered Institute of Journalists. CloJ Code of Conduct, 2014. Available at: http://cioj.co.uk/the-cioj-code-of-conduct-for-our-members/ Accessed: 01 Aug. 2014).

Contempt of Court Act 1981. London: Her Majesty's Stationery Office. Available at: http://www.legislation.gov.uk/ukpga/1981/49 Accessed: 01 Aug. 2014.

CRAVEN, N. How Police Hacked Mail on Sunday Phone. Mail Online, 4 Oct. 
2014. Available at: http://www.dailymail.co.uk/news/article-2780809/ How-police-hacked-Mail-Sunday-Officers-used-anti-terror-laws-seizephone-records-identify-source-exposed-Chris-Huhne-s-speeding-pointsfraud.html Accessed: 01 Oct. 2014.

Data Retention and Investigatory Powers Act 2014. London: The Stationery Office. Available at:http://www.legislation.gov.uk/ukpga/2014/27/contents/enacted Accessed: 01 Oct. 2014.

DAVIES, N. Flat Earth News. London: Vintage, 2009.

Department for Culture Media and Sport; JAVID, S. Final Royal Charter on Self-Regulation of the Press. 30 Oct. 2013. Available at: https:// www.gov.uk/government/publications/leveson-report-cross-partyroyal-charter Accessed: 01 Aug. 2014).

Digital Rights Ireland Ltd (C-293/12) v Minister for Communications Marine and Natural Resourcesand Othersand KärntnerLandesre gierung(C-594/12)and others. Available at: http://curia.europa.eu/ juris/document/document.jsf?doclang $=E N \&$ text $=\&$ pagelndex $=0 \&$ part $=1$ $\&$ mode=DOC\&docid $=150642 \&$ occ $=$ first $\&$ dir $=\& c i d=179393$ Accessed: 01 Oct. 2014.

DODD, M; HANNA, M. McNae's Essential Law for Journalists. Oxford: Oxford UniversityPress,2014.

ELLISON, S. The Man Who Spilled the Secrets. Vanity Fair, 01 Feb. 2011. Available at: http://www.vanityfair.com/politics/features/2011/02/theguardian-201 102.print Accessed: 01 Oct. 2014.

FENWICK, H; PHILLIPSON, G. Media Freedom Under the Human Rights Act. Oxford: Oxford University Press, 2006.

FRANKLIN, B (ed.); CARLSON, M (ed.). Journalists Sources and Credibility. New York and London: Routledge, 2013.

Independent Press Standards Organisation. Editors' Code of Practice, 2014. Available at: https://www.ipso.co.uk/IPSO/cop.html Accessed: 01 Aug. 2014.

International Federation of Journalists. IFJ Code of Principles on the Conduct of Journalism, 1954. Available at:http://ethicaljournalisminitiative.org/en/contents/ifj-code-of-principles-on-the-conduct-of-journalism Accessed: 01 Aug. 2014.

KHATCHADOURIAN, R. No Secrets: Julian Assange's Mission for Total Transparency. The New Yorker, 7 Jun. 2010. Available at: http://www. newyorker.com/magazine/2010/06/07/no-secrets Accessed: 01 Jan. 2015).

KELLER, B. Dealing with Assange and the Wikileaks Secrets. The New York Times, 26 Jan. 2011. Available at: http://www.nytimes. 
com/2011/01/30/magazine/30Wikileaks t.html?pagewanted=all\&_r=0 Accessed: 01 Oct. 2014.

MAY, A. 2013 Annual Report of the Interception of Communications Commissioner. London: OGL, 2014. Available at: http:// www.iocco-uk.info/sections.asp?section $I D=1 \&$ type=top $\quad$ Accessed: 01 Aug. 2014.

Mersey Care NHS Trust v Ackroyd[2007] EWCA Civ 101. Available at:http://www.5rb.com/case/mersey-care-nhs-trust-v-ackroyd-no-2-ca/ Accessed: 01 Aug. 2014.

Metropolitan Police. Operation Alice Closing Report. 01 Sep. 2014. Available at: http://content.met.police.uk/News/Operation-Ali ce/1400026158081/1257246745756 Accessed: 01 Oct. 2014.

NATHAN, G. Court-Ordered Disclosure of Journalists' Confidential News Sources in England: British Steel Corp. v. Granada Television Ltd. Boston College International and Comparative Law Review, v. 7, n. 2, 1984, p. 517-539.

National Union of Journalists. NUJ Code of Conduct, 2011 . Available at: http://www.nuj.org.uk/about/nuj-code/ Accessed: 01 Aug. 2014.

Parliamentary Assembly of the Council of Europe. Recommendation 1950 (2011): The Protection of Journalists' Sources, 25 Jan. 2011. Available at: http://assembly.coe.int/Main.asp?link=/Documents/AdoptedText/ta11/EREC1950.htm\#1 Accessed Aug. 2014.

Police and Criminal Evidence Act 1984. London: Her Majesty's Stationery Office. Available at: http://www.legislation.gov.uk/ukpga/1984/60/ contents Accessed: 01 Aug. 2014.

Regulation of Investigatory Powers Act 2000. London: The Stationery Office Ltd. Available at: http://www.legislation.gov.uk/ukpga/2000/23/contents Accessed: 01 Aug. 2014.

TRAVIS, A. Police Told to Reveal Use of Surveillance Powers to Identify Journalists' Sources. The Guardian, 6 Oct. 2014. Available at: http:// www.theguardian.com/uk-news/2014/oct/06/police-ordered-reveal-ripa-powers-identify-journalists-sources Accessed: 01 Oct. 2014.

WEBSTER, F. Theories of the Information Society. London and New York: Routledge, 2014.

Wikileaks. About. 16 Feb. 2008. Available at:

http://web.archive.org/web/20080216000537/http://www.wikileaks. org/wiki/Wikileaks:About\#Wikileaks_has_1.2_million_documents.3F Accessed: 01 Oct. 2014.

.About. 5 Jul. 2011. Available at: http://www.wikileaks.org/ About.html Accessed: 01 Oct. 2014. 
WINTOUR, P. British Police's Use of RIPA Powers to Snoop on Journalists to be Reined In. The Guardian 12 Oct. 2014. Available at: http://www. theguardian.com/world/2014/oct/12/police-ripa-powers-journalistssurveillance Accessed: 01 Oct. 2014.

ZION, L. (ed.); CRAIG, D. (ed.). Ethics for Digital Journalists. New York and London: Routledge, 2014.

Melanie Dupéré is a tenured Lecturer at the University of La Réunion (France), where she is responsible for coordinating English Studies within the Faculty of Law and Economics on the southern campus. She is a member of the Centre de recherches en civilisation britannique within the Center for Research on the English-Speaking World at the University of Sorbonne Nouvelle Paris III and her current phD research project focuses on the freedom of the press in the United Kingdom since 1998. 